\title{
Structural Transformation of the Turkish Economy under the Scope of Sustainable Development ${ }^{1}$
}

\author{
Hacer Simay Karaalp-Orhan ${ }^{a}$
}

\begin{abstract}
The distribution of the labour force by sectors and the country economic structure indicate the economic development level of countries. The traditional sectoral transformation is observed in all countries during the economic development process. Since the establishment of the Republic of Turkey, industrialization has been one of the fundamental development policies to be achieved. As an inevitable result of the development, the sectoral distribution of production and employment changed in Turkish economy over the years. This structural transformation is associated with the transition from primary sector to capital intensive production structure in which the manufacturing and the service sectors expand while the agricultural sector shrinks. However, the agricultural sector is still important in Turkey. Today, approximately one-fifth of the labour force is employed in the agricultural sector. This ratio shows the developing country feature of Turkish labour market despite the industrialization and urbanization policies and the structural changes in recent years. In this context, the aim of this study is to analyze the sectoral transformation of the Turkish economy within the scope of the sectors share in the GDP of Turkey and the share of sectors in the total employment, within the changing structure of the labour market and the level of urbanization.
\end{abstract}

Keywords: economic development, structural transformation, Turkish economy

\section{Introduction}

Structural transformation or structural change is the prerequisite not only for the process of the economic development, but also rising per capita income and higher productivity growth. Moreover, structural transformation helps to achieve greater diversity of the economic structure, which creates a country's resilience to vulnerability to poverty and external shocks (Oyelaran-Oyeyinka \& Lal, 2017) and also to provide sustainable development. Structural transformation is defined as the shift and transition of an economy's structure from low-productivity, labour intensive-primary economic activities to higher productivity, capital and skill (technology) intensive industrial activities. Furthermore, it is the reallocation of labour across sectors with different productivity levels (Timmer et al. 2014). On the other hand, while structural change can be defined as an alteration in the relative importance of economic sectors, it also affects the urbanization, migration, production techniques, specialization, productivity, agglomeration economies, skills and educational requirements and structure of the labour market, income inequality and poverty, the change of consumption patterns, adaptation of the advanced technology and export patterns of a country. The processes of structural change that accompany economic development are jointly referred as economic transformation. This economic transformation affects and leads the development and

${ }^{1}$ This study was supported by Scientific Research Coordination Unit of Pamukkale University under the project number 2019KKP065. 
industrialization process of advanced countries. Structural transformation is a long-term shift and in the broad sense, it involves the alteration (modernization) of a country's economy, society and institutions. Moreover, it has an effective role in changing values, norms, beliefs and customs in the transformation from a traditional to a modern society. As stated in the study of Monga (2013) structural change is also the foundation of sustainable and inclusive growth and the condition for achieving the sustainable development goals. As a developing country, industrialization has been one of the main development policy to be achieved in Turkey. As an inevitable result of the development, under the scope of the structural transformation, the sectoral and employment distribution of production in Turkey's economy has changed over the years. However, despite the industrialization and urbanization policies sectoral transformation is fail to create sufficient industrial jobs in Turkey. The ongoing importance of agricultural employment in the economy indicates the emerging feature of the Turkish labour market. Moreover, the imbalances in the sectoral distribution of employment raises some structural problems in Turkish economy such as income inequalities across sectors, rural to urban migration, rural poverty increase, agglomeration of unskilled and uneducated labour force in urban areas, increasing unemployment in cities and informal employment, removing many rural migrant women from the labour market in the cities, resulting in a low labour force participation rate. In this context, the main objective of this study is to analyze the sectoral transformation of Turkish economy under the scope of alternation of sectoral components of Turkish GDP and labour market, urbanization and migration. This study is structured as follows. Section 2 explains the relationship between economic development and structural transformation; Section 3 presents the economic growth and sectoral composition of Turkish GDP. Section 4 and Section 5 analyze the change of population and the transformation of Turkish labour market, respectively and Section 6 concludes the study.

\section{Economic Development and Structural Transformation}

The notion of structural change is one of the central concepts in development economics. Structural change was first introduced by Lewis (1955) with the Lewis Model (Lewis Dual Sector Model), known as the two sector models of agriculture (primary sector) and industry (secondary sector). According to Fisher, economic progress will lead to the emergence of the service sector (tertiary sector), which follows the development of the primary and secondary sectors. Primarily Allen Fisher (1935) developed the Lewis model. Later, Colin Clark (1940) introduced the Clark-Fisher development theory and developed the Fisher-Clark Theory of Structural Change. According to the-Fisher-Clark 3 sector model, the sectoral distribution of the labour force will return from the agricultural sector to industry and then to the service sector with economic development. In this context, following the work of Allen Fisher (1935) and Colin Clark (1940)) or Fourastie (1949), in the 1950s, one of the major concerns of the development economy for Arthur Lewis, Albert Hirschman, and Raul Prebisch was the ability of the economic system to absorb the entire working population in productive activities (Lavopa, 2015). In the view of the development economists, structural change will take the less developed countries out of poverty and save the dual economic structure that hinders 
the development. Kuznets (1973) points to structural change, by the massive shift of labour away from agriculture, as one of the six main characteristics of modern economic growth. According to the sectoral distribution, which mainly consists of agriculture (and mining) -primary sector, industry (and construction)-secondary sector and services sectors (tertiary sector), the production and the employment of the countries are predominantly in the agricultural sector in the early stages of economic development. As the countries develop, the share of the industrial sector in the economy and employment of the country increases and the industrialization triggers a rapid increase in the share of manufacturing in the economy. The increasing use of mechanization in the agricultural sector rise the productivity of agricultural workers. Nevertheless, the driving effects of the shrinking economic activities and jobs in rural areas and the effect of industrialization in the cities and the attractive effects of better working and living conditions cause the population to migrate from rural areas to cities. Thus, the economic structure in the country changes with urbanization and industrialization. In developed industrial economies, with the structural transformation diversity in production and urbanization, sectors related to services such as education, health, banking, tourism and shopping have emerged and the labour force has shifted from the industrial sector to the services sector. Therefore, development involves the modernization of a country's economy, society and institutions. Briefly, the structural transformation in an economy is based on these following interrelated processes. A decreasing share of GDP and employment in agriculture; rural-to-urban migration, supported by rural and urban development; the rise of a modern industrial and service economy and a demographic transition with better living conditions also transforms the economies, societies and the environment. Through development and structural change, the rise of productivity in agricultural sector pulls up wages in the sector, provides food, increases savings and gradually eliminates the absolute poverty. However, the increase in productivity will be more rapidly in the industry and service sectors (Oyelaran-Oyeyinka \& Lal, 2017). Increase in productivity of an economy will help to achieve higher standards of living conditions, greater wealth and sustainable development. Structural change is a necessary but not a sufficient condition for a country to achieve the sustainable development goals. Economic transformation should first increase the number of decent jobs and the productivity capacities of developing countries with increasing productivity. By increasing resource efficiency, structural change will contribute to a variety of sustainable production and consumption patterns. Economic transformations for sustainable development must be based on the reform of the relationships between the environment, the economy and society. New mindsets and behaviors, incentives and shared values must work towards a sustainable future (ESCAP, 2016). However, the success of countries in economic development and becoming an egalitarian welfare state depends on the dynamism of a modern sector that can absorb the increasing share of the labour force, increase the productivity and reduce the technological gap compared to the other countries (Lavapova, 2015). Otherwise, the economy will lead to a low-income or middle-income trap with high unemployment rate, increasing risk of poverty, urban sprawl, congestion, inequalities, pollution and lack of affordability (ESCAP, 2016). 


\section{Economic Growth and Sectoral Composition of Turkish GDP}

Structural change is typically examined by looking at the development of the shares of sectors in total economic activity. The distribution of the labour force and the economic structure by sectors indicate the economic development level of countries. Differences between the employment and value added shares reflect cross-sector differences in labour productivity (Van Neuss, 2019). The speed and scope of the sectoral shifts reflect the willingness and ability of labour and capital to address the high productivity sectors and all these factors affected by the policy and institutional environment (ESCAP, 2016).

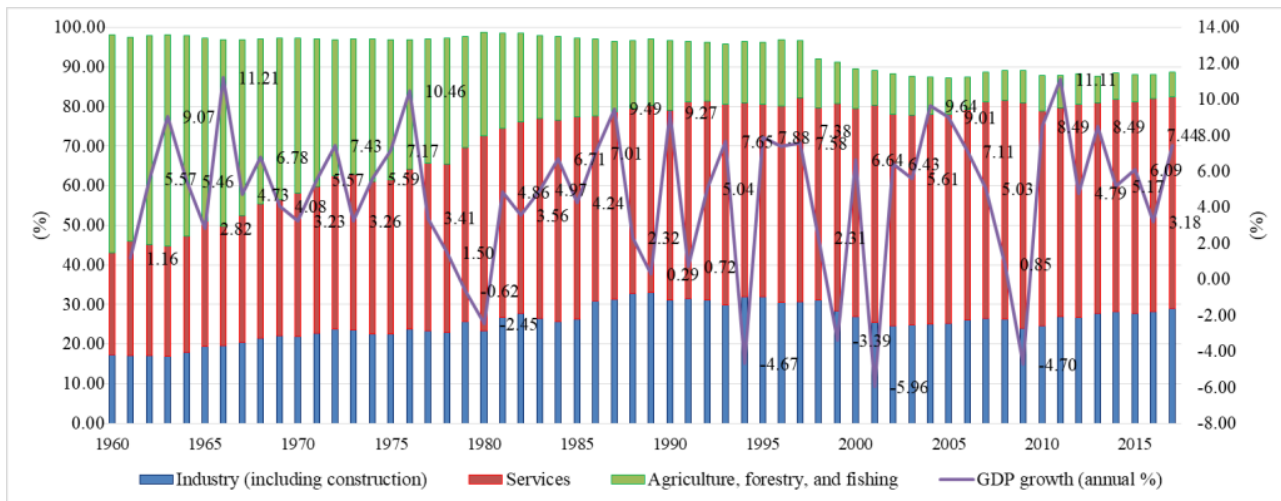

Figure 1. Sectoral V alue Added (\% of GDP) and Economic Growth Rate (\%)

Source: World Bank (2019), WDI

Figure 1 indicates the share of sectors value added in the GDP and the GDP growth rate from 1960 to 2017 . While the average growth rate of Turkey was $5 \%$ over the period of 1960-2017, an inconsistent economic growth was found with fluctuations. This implies that economic growth of Turkey is not sustainable and affected from internal and external economic crises and political turmoil. GDP contribution of the sectors in Turkey is changing dramatically with the economic transformation. This structural transformation is associated with the transition from agricultural sector to industry and service sector. In 1960, the agricultural sector's share in GDP of Turkey value added value accounted for more than half. Turkish economy based on the agricultural sector. In 1960, the largest share of GDP was in the agricultural sector with $54.9 \%$, followed by the contribution of services and industry sector to $25.8 \%$ and $17.3 \%$, respectively. The share of the manufacturing sector was only $12.7 \%$. Since the establishment of the Republic of Turkey, industrialization has been one of the fundamental development policies to be achieved. Throughout the period, while the share of industry (and manufacturing) and service sectors expanded, the agricultural sector contracted. In particular, following the decision of the $24^{\text {th }}$ January 1980, Turkey adopting neo-liberal policies and Turkish economy liberalized the trade through free market economy and export-led growth model. After then, Turkish economy has adopted a structural change policy and mainly focused on the industrialization and exports. In 1981, while share of agriculture to Turkish GDP dropped to $24.1 \%$, the share of service and industry sectors 
increased to $47.7 \%$ and $26.6 \%$, respectively. Another turning point for Turkish economy was the year of 1989 in which the financial liberalization was occurred through the liberalization of foreign exchange transactions and capital movements. In 2017, the share of services and industry sectors in GDP increased to $53.3 \%$ and $29.1 \%$, respectively. The share of agricultural sector decreased to $6 \%$. Although the contribution of the agricultural sector to GDP shrinks, it is still an important sector in terms of the contribution of a significant number of labour force in Turkey.

\section{Urbanization, rural and urban population}

It is clear that, there is a relationship between structural transformation, industrialization and urbanization. Sustainable development and urbanization are the key factors of economic change (Oyelaran-Oyeyinka \& Lal, 2017). Through the development process, the increasing use of the technology in the primary sectors and industrialization leads to internal migration and urbanization. Urbanization leads to shifts in family formation, gender relations, personal status, poverty and employment creation. However, most of the developing countries face the dilemma of big city problems with increasing unemployment, poverty and inequality. The high migration of uneducated and unskilled of labour from villages to cities may cause socio-economic problems unless absorbed by the urban labour market

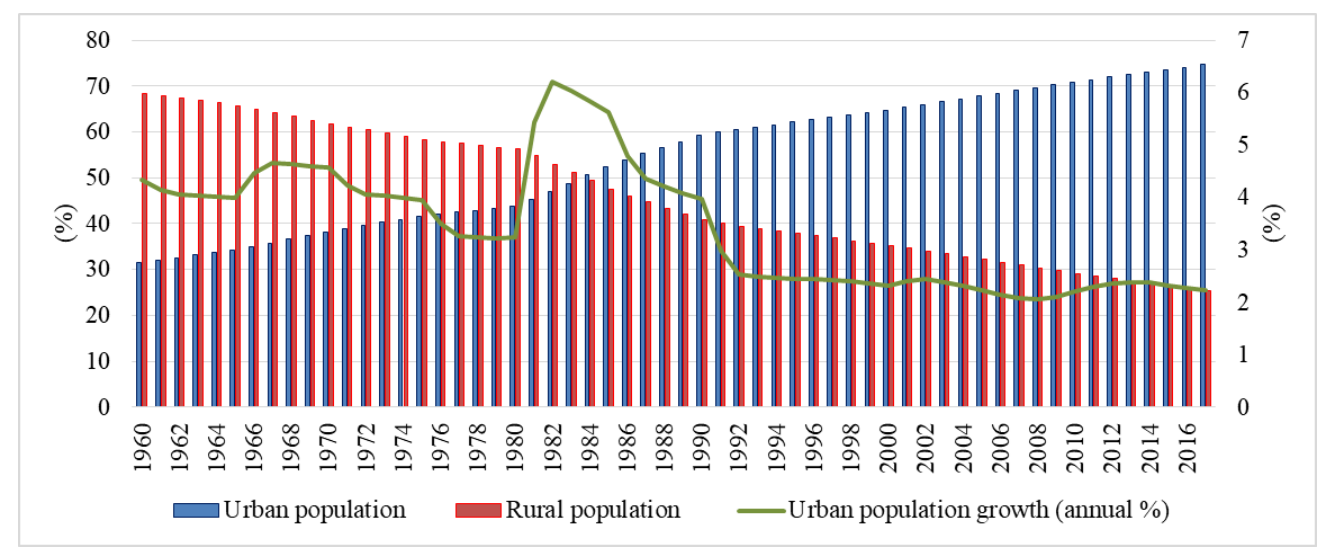

Figure 2. Rural and Urban Population (\% of Total Population) in Turkey

Source: World Bank (2019), WDI

Rapid urbanization and migration from rural to urban areas in Turkey began after 1950. At the beginning of 1950 s, approximately $75 \%$ of the country's population lives in rural areas. In 1950s, the mechanization of agricultural sector triggered the structural change in the economy. On the one hand, the transition to a market economy instead of subsistence farming, the fragmentation of agricultural land, the disadvantages of smallscale enterprises, the increase in unemployment, low per capita income, inadequate facilities and socio-cultural problems caused the surplus of agricultural labourers to move to cities. On the other hand, the economic, social, cultural, educational, health and job opportunities that offered by the urban area increase the attractiveness of the migration. 
After 1980, urbanization increased significantly through industrialization, the growth of the tourism sector and the impact of terrorist attracts in the Eastern part of the Turkey (Iş1k, 2005). While the share of rural population to total population was $68 \%$ in 1960 , it decreased to $25 \%$ in 2017 . The urban population growth rate was $4 \%$ in the 1960 s and it was decreased to 3\% between 1970 and 1980 because of the agricultural support purchases, migration of unskilled rural workforce to Germany, reduction of birth rate, economic and political turmoil, decrease in investments in the cities and insufficient infrastructure (Iş1k, 2005). In the 1980's, urban population growth rate increased to 4\% while the rural population growth rate was negative. From the 1990s until today the urban population growth rate in Turkey stabilize to $2 \%$.

\section{Structural Change of the Labour Market in Turkey}

The structure of labour market and the sectoral distribution of production and employment changed in Turkish economy over the years. The transformation of the labour market is also concomitant with the changing importance of sectors. In this context, the fundamental labour market indicators for Turkey are shown in Figure 3.

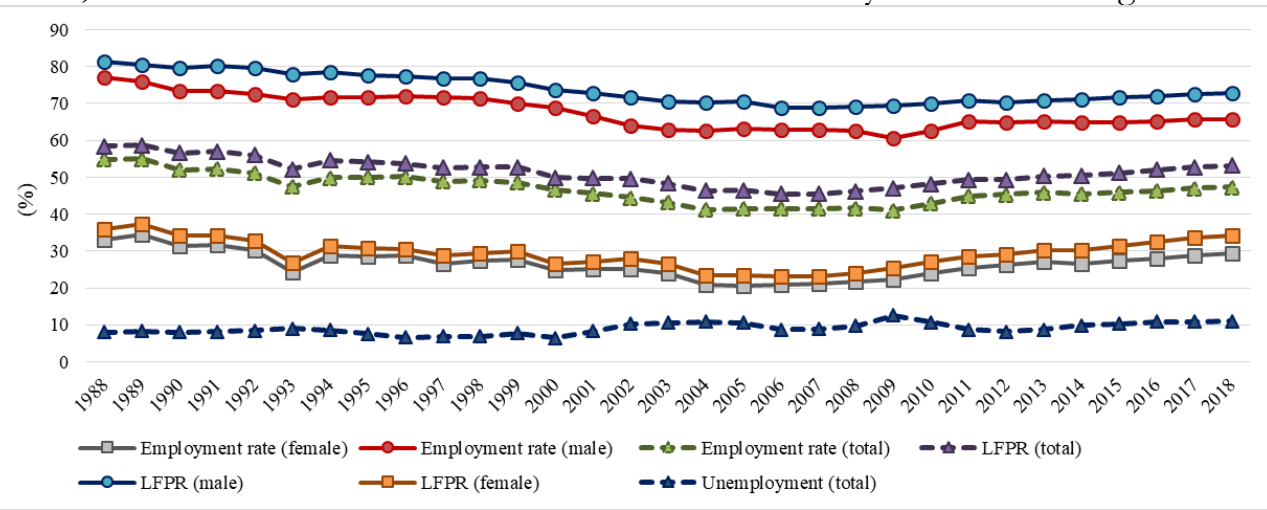

Figure 3. Labour Market Indicators in Turkey (Non-institutional Population, +15 age)

Source: World Bank (2019), WDI

Especially the participation of women to the labour market is related with the economic development and the structural transformation. Turkish labour market is generally characterized by a low labour force participation rate (LFPR) due to the low labour force participation of women. On the one hand, it could relate, to some extent, to the deeprooted traditional gender roles (socio-cultural), and on the other hand, to the economic barriers and sectoral transformation in Turkey. The process of urbanization and agricultural shedding are the two driving forces contributing to this decreasing trend. The U-shaped hypothesis that describes the relationship between female LFPR and the economic development (structural shifts in economic sectors and changes to household labour supply and attitudes about women working outside the home). During the structural shift of the economy, women who migrate from rural areas to urban remain out of the labour market or get involved in the informal economy because of not possessing the qualifications required by the labour force in the city (Karaalp-Orhan, 
2017). According to the World Bank (2019) WDI indicators, while the female LFPR was $65.4 \%$ in 1960 , it decreased to $50.8 \%$ and $46.2 \%$ in 1970 and 1980 , respectively. The reduction of FLFPR continued till 2006. In 2006, the FLFPR was dropped to $23 \%$ and then started to increase gradually. In 2018, although FLFPR is increased to $34.2 \%$ quite low relative to male LFPR $72.7 \%$. Moreover, the employment rate of women $(28.8 \%)$ was far below to men $(65.6 \%)$ in 2018. Another issue that continues in Turkish labour market is persistently high unemployment rate. The average unemployment rate was 9\% over the period of $1988-2018$ and increased to $10.8 \%$ in 2018.

\subsection{Sectoral Distribution of Employment}

Turkish labour market shows the feature of a developing country. Imbalances in the sectoral distribution of employment in Turkey also bring some structural problems. The major difference between sectors leads to income inequality between them. With the impoverishment of the workers in the agricultural sector, migration from rural to urban areas and shifting of the labour force to other sectors has emerged as an important problem in that the population solved from agriculture will be employed in cities. The labour force, which did not meet the quality demanded by the urban labour market created unskilled masses in cities and they shifted to the informal sectors and also increased the urban unemployment rate. Moreover, due to the lack of employment opportunities in the industrial sector, this unskilled labour force leads to an unhealthy growth of the service sector (Murat, 2007). On the other hand, women working as unpaid family workers in agriculture while continuing to remain outside the urban labour market, do not only create structural labour market problems, but also leads to the economic efficiency and social problems in Turkey.

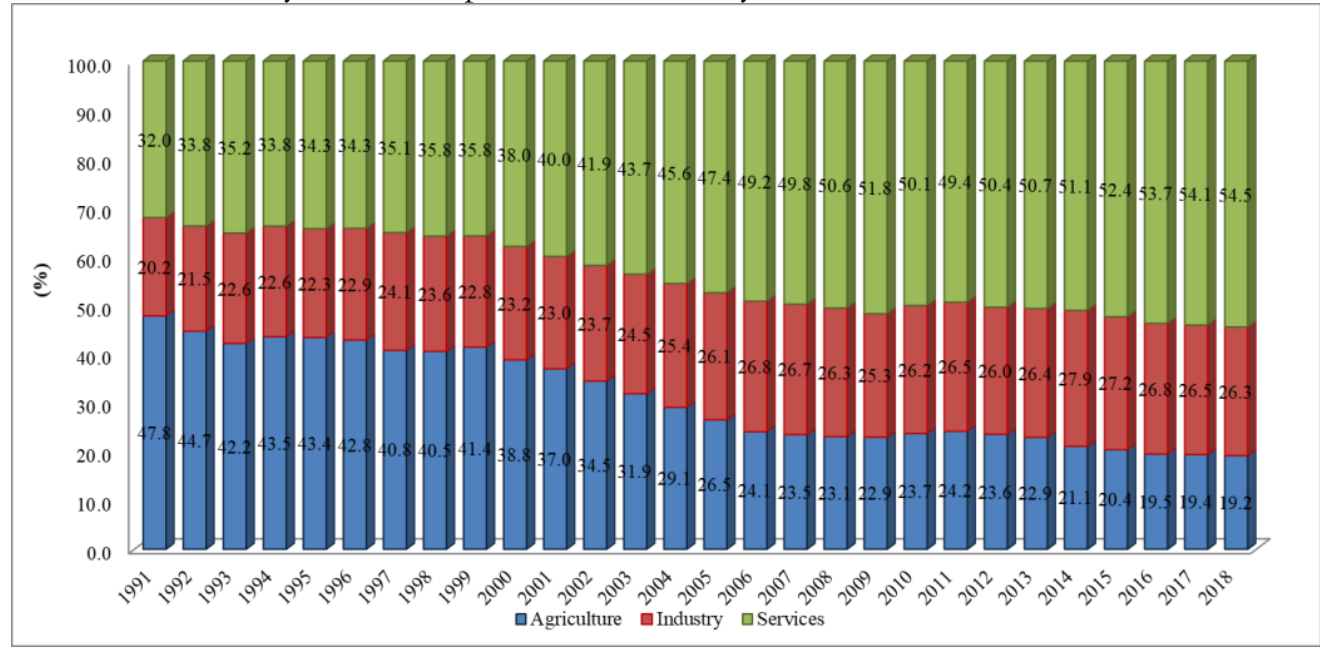

Figure 4. Sectoral Distrbution of Employment (\%)

Source: World Bank (2019), WDI

Figure 4 shows Turkey's changing employment structure. In 1991 while the majority of the workforce employed in the agricultural sector $(47.8 \%)$, the share of service and industry sector was $32 \%$ and $20.2 \%$, respectively. Through the structural transformation, the share of the agricultural sector in total employment is significantly reduced. In 2018, 
while the share of agriculture in employment decrease to $19.2 \%$, the employment share of service and industry increase to $54.5 \%$ and $\% 26.3 \%$, respectively. Although the agricultural sector has the lowest share in GDP with the economic transformation, the share of the sector in employment decreases more slowly. Almost one fifth of total employment $(19.2 \%)$ is employed in the agricultural sector, but the contribution of the workers in this sector to GDP is only $9.2 \%$. This situation is considered as an indicator of low productivity in the agricultural sector and hidden unemployment, which is a characteristic feature of the agricultural sector. On the other hand, although the share of employment in the agricultural sector has decreased considerably, it is still quite high in Turkey compared to other countries. For this reason, sector preserves its importance in the economy and this situation also indicates the developing countries feature of the Turkish labour market. During the sectorial change, the industrial sector failed to absorb all the excess surplus labour in the agricultural sector. Similar contradiction faced by many developing countries also happens in Turkey. The low-skilled labour flows from agriculture to low-productivity activities in the service sector, instead of faster-growing and requiring higher-productivity jobs in the production of tradable goods in the formal manufacturing sector, they are used for unskilled jobs in the construction sector or are often exploited as low-cost cheap labour for international competition.

\subsection{Employment status}

According to the employment status, employment is divided into four groups as wage and salaried workers, employers, self-employed and unpaid family workers. The distribution of employment by status in a country provides information about the socioeconomic development level of the country. Most of the employment consists of wage and salaried workers in developed countries, while employment is mostly composed of unpaid family workers and self-employed workers in developing countries.

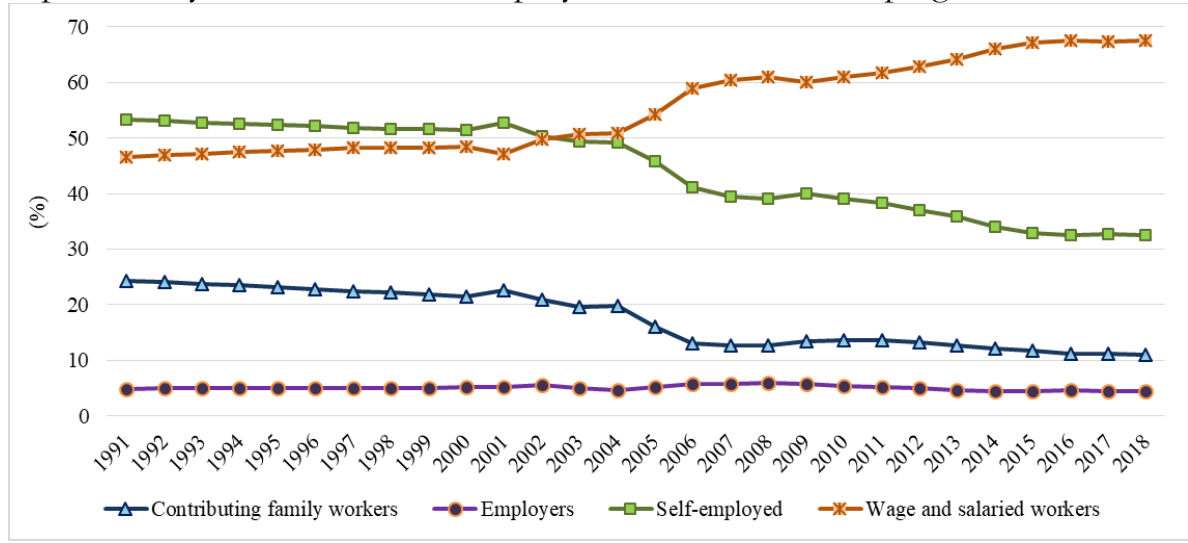

Figure 5. Employment Status (\%)

Source: World Bank (2019), WDI

Figure 5 indicates the transformation of employment status in Turkey. In 1991, the share of self-employed was the highest $(53.3 \%)$ and decreased to $32.5 \%$ in 2018 . The beginning of the 2000's was a breaking point in which there was a significant change in employment status. While the share of self-employed and unpaid family workers 
decreased, the share of wage and salaried workers increased significantly. This downward trend can specifically be explained by the structural transformation resulting from the the shrinkage of the agricultural sector, increasing urbanization, and migration. Especially, women in the agricultural sector are employed as unpaid family workers. Although seen a slight increase since the mid-2000s, employers have the lowest share in the Turkish labour market. This indicates that there are fewer entrepreneurs and capital; however, the share of employers decreased slightly after the 2008 economic crisis.

\section{Conclusion}

Structural transformation is necessary for economic development, but at the same time, the increase in per capita income, higher productivity growth, industrialization and modernization of a country is essential to eliminate poverty and inequality. During the economic development and structural change, the expansion of GDP per capita has been accompanied by a decline in the share of agriculture in employment and the share of value added in total GDP. By contrast, the share of industry and services has risen. Through the structural transformation and so-called economic transformation the changes in the production structure also changes educational requirements and the relative positions of different groups in the society.

As an inevitable result of the development, the scope of the structural transformation, the sectoral distribution of production and employment in Turkish economy has changed over the years. Rapid urbanization and migration from rural to urban areas in Turkey began after 1950 after the mechanization of agricultural sector. With the liberalization and the export-led growth policies in 1980, the speed of transformation increased. While $75 \%$ of population lived in the rural areas in $1950 \mathrm{~s}$, it decreased to $25 \%$ in 2017 and the share of urban population to total employment increased to $74.6 \%$ in 2017. However, like the most of the developing countries Turkey faces an important challenge. The absorption capacity of the industrial sector to surplus labour in the agricultural sector is not sufficient in Turkey. In other words, the sectoral transformation in Turkey is failed to increase productivity and to create sufficient formal industrial jobs. In 1960, the share of agricultural sector value added in Turkey's GDP accounted for more than half and it is decreased to $6 \%$ in 2017 with the share of services and industry sectors in GDP increased to $53.3 \%$ and $29.1 \%$, respectively. While the employment share of service and industry increase to $54 \%$ and $\% 26 \%$, respectively, the employment share of agricultural sector also decreased to $19.4 \%$ in 2017 . Although the agricultural sector has the lowest share in GDP with the economic transformation, the share of the sector in employment decreases more slowly. Approximately one-fifth of the labour force is employed in the agricultural sector, but their contribution to the value added in the GDP is only 6\%. This situation is considered as an indicator of low productivity and hidden unemployment in the agricultural sector. Although the share of employment in agricultural sector is decreasing significantly, it is still quite high in Turkey compared to other countries. Moreover, the unskilled rural migrants, who cannot meet the quality demanded by the urban labour market and also the labour-saving technological changes in the industrial sector have created unskilled masses in the cities and they shifted to lowproductivity activities in the service sector, instead of faster-growing and requiring higher-productivity jobs in the production of tradable goods in formal manufacturing 
sector. Moreover, they are also employed in unskilled jobs in the construction sector and usually exploited as low paid cheap labour for international competition. This also cause to increased urban unemployment rate and poverty, contributing to informal sector expansion, the working poor phenomenon, metropolitan city problems where thousands of people living in the slums with inadequate infrastructure. On the other hand, women who is working as unpaid family workers in the agriculture sector remain out of labour market not only creates structural labour market problems, but also causes economic efficiency and social problems in Turkey. However as Lavapova (2015) points out the success of countries' economic development and prosperity depends on the dynamism of a modern sector that can absorb the increasing share of the workforce and reduce the technological gap compared to the other countries. Otherwise, the economy will lead to low-income or middle-income trap with high unemployment rate, increasing risk of poverty, inequality and urban problems. In this context, Turkey needs to implement new policies to increase productivity and ensure the reallocation of labour across sectors. Incompatibility between job and skill problems and unqualified, low educational level of labour force should be improved. Improving of the quality education and childcare facilities for women is critical to earning employment outcomes and opportunities for better jobs. Migration from rural areas to urban can be slow down through the subsidies, agricultural sector regulation and establishment of agro industries in rural areas.

\section{References}

Clark, C. (1940). The Conditions of Economic Progress, Macmillan, London.

ESCAP (2016), "Transformations for Sustainable Development", Retrieved from https://www.unescap.org/sites/default/files/Full\%20report.pdf, (21.0.2019).

Fisher, A.G.B. (1935), The Clash of Progress and Security. London: MacMillan \& Co. Ltd.

Fisher, A.G.B. (1939), Production, Primary, Secondary and Tertiary, The Economic Record, 15(1): 24-38.

Fourastié, J. (1949) Le Grand Espoir du XXe Siècle. Paris: Presses Universitaires de France. Reprinted as

'Moderne Techniek en Economische Ontwikkeling' (1965). Amsterdam: Het Spectrum.

Işık, Ş. (2005), Türkiye'de Kentleşme ve Kentleşme Modelleri, Ege Coğrafya Dergisi, 14(2005):57-71.

Karaalp-Orhan (2017), What are the Trends in Women's Labour Force Participation in Turkey?, European Journal of Sustainable Development, 6(3): 303-312

Kuznets, S. (1971), Economic Growth of Nations: Total Output and Production Structure. Cambridge

Massachusetts: The Belknap Press of Harvard University Press.

Lavapo, A.M. (2015), "Structural Transformation and Economic Development. Can Development Traps be Avoided?", Doctoral Dissertation, Datawyse, Universitaire Pers Maastricht : Maastricht.

Lewis, W.A. (1955). The Theory of Economic Growth, Richard D. Irwin Inc, Homewood, Illinois.

Murat, S. (2007). "Dünden Bugüne İstanbul'un İşgücü ve İstihdam Yapısı", İTO, Yayın No: 2007-73, İstanbul.

Monga, C. (2013). Winning the jackpot: Jobs dividends in a multipolar world. In J. E. Stiglitz, J. Y. Lin, \& E. Patel (Eds.), The industrial policy revolution II-Africa in the 21st century (pp. 135-171). New York: Palgrave MacMillan.

Oyelaran-Oyeyinka, B. and Lal, K. (2017), Structural Transformation and Economic Development: Cross regional analysis of industrialization and urbanization, Routledge: NewYork.

Timmer, M.P., Vries, G. and Vries, K. (2014), Patterns of Structural Change in Developing Countries, Groningen growth and development centre, University of Groningen, Retrieved from http://www.ggdc.net/publications/memorandum/gd149.pdf, (20.06.2019).

World Bank (2019), World Development Indicators, Retrieved from https://databank.worldbank.org/source/world-development-indicators\#, (20.06.2019).

Van Neuss, L. (2019), The Drivers of Structural Change, Journal of Economic Surveys, 33(1): 309-349. 